\title{
The Effect of Prices and Promotions on Purchase Decisions on Cement at PT. Semen Baturaja (Persero), Tbk
}

\author{
Muhammad Beni, Zakaria Wahab, Marlina Widiyanti
}

\begin{abstract}
Purchase decisions are actions taken by consumers to make a product purchase. This research has purpose to analyze how much influence prices and promotions on cement purchase decisions at PT. Semen Baturaja (Persero), Tbk and the dominant influential variables. The sample numbers in this research by using 150 (one hundred fifty) respondents. The technique used in sampling of this research was purposive sampling. The method of analysis is by using multiple linear regression analysis. The results of the analysis in this research indicate that the price and promotion variables have a positive value and significant effect on purchase decisions and independent variable that has a positive value, significant influence and dominant influence is the price variable on cement purchase decisions at PT. Semen Baturaja (Persero), Tbk

Keywords: Price, Promotion, Purchase Decision
\end{abstract}

\section{INTRODUCTION}

PT. Semen Baturaja (Persero) Tbk is a Company that operates in the cement industry and has Head Office in Palembang, South Sumatra. Initially, the Company was founded in 1974. The type of cement produced is Cement Ordinary Portland Cement (OPC) Type I according to SNI 2049: 2015, Portland Composite Cement (PCC) Type I according to SNI 7064: 2014, Ordinary Portland Cement (OPC) Type II according to SNI 2049: 2015, Ordinary Portland Cement (OPC) Type V according to SNI 2049: 2015 So that it can reach markets in several cities in the Southern Sumatra Province, namely Jambi, Bangka Belitung, Lampung, Bengkulu, and Palembang. Based on data from the Indonesian Cement Association (ASI), it was explained that the growth of cement consumption in Indonesia showed a positive increase, the average per year reached $4,8 \%$ in the period 2011-2018.

In 2018 the production capacity was 109.9 million tons while the national cement consumption was 69,5 million tons. This shows that the national cement production capacity have surplus amount compared to domestic demand. Refer to Table 2, it is described that the development of construction and infrastructure development is generally in Indonesia, and

Revised Manuscript Received on August 14, 2019.

* Correspondence Author

Muhammad Beni*, Candidate Master of Management in Magister Management University of Sriwijaya, Indonesia.

Dr. Zakaria Wahab, M.B.A, Lectures in Faculty Economic University of Sriwijaya, Indonesia.

Hj. Marlina Widiyanti, S.E., S.H., M.M., Ph.D., Lectures in Faculty Economic University of Sriwijaya, Indonesia.

(c) The Authors. Published by Blue Eyes Intelligence Engineering and Sciences Publication (BEIESP). This is an open access article under the CC BY-NC-ND license (http://creativecommons.org/licenses/by-nc-nd/4.0/) especially in Southern Sumatra, the need for cement has increased significantly. In the year of 2017 PT. Semen Baturaja (Persero) Tbk. has increased cement production from 2 (two) million tons to around 3.85 (three point eighty five) million tons per year. The increase in production volume have to be in line with the increase in sales volume, in the current conditions, the number of cement brands and cement production in Indonesia and in the Southern Sumatra region continue to increase.

Table 1. Growth in Cement Sales in Indonesia

\begin{tabular}{ccc}
\hline Year & $\begin{array}{c}\text { Cement Sales in } \\
\text { Indonesia } \\
\text { (Million Ton) }\end{array}$ & Growth (\%) \\
\hline 2011 & 48 & 20 \\
2012 & 55 & 14,5 \\
2013 & 58 & 5,6 \\
2014 & 60 & 3,3 \\
2015 & 61 & 1,8 \\
2016 & 62 & 1,0 \\
2017 & 66 & 7,6 \\
2018 & 70 & 4,8 \\
\hline
\end{tabular}

Source: Indonesian Cement Association (ASI), processed results.

Table 2. Market Share based on Manufacturers in 2018

\begin{tabular}{clrc}
\multirow{2}{*}{ No. } & \multicolumn{1}{c}{ Company } & \multicolumn{2}{c}{ Domestic Sales } \\
\cline { 2 - 4 } & & $\mathbf{2 0 1 8}$ & Share \% \\
\hline 1 & PT. Semen Padang & 6.366 .723 & 9,2 \\
2 & PT. Semen Gersik & 15.834 .652 & 22,8 \\
& (Persero), Tbk & 5.220 .125 & 7,5 \\
3 & PT. Semen Tonasa & 10.630 .577 & 15,3 \\
4 & PT. Lafarge Holcim & & \\
& Indonesia, Tbk & 17.741 .356 & 25,5 \\
5 & PT. Indocement Tunggal & & \\
& Prakarsa, Tbk & 2.196 .595 & 3,2 \\
6 & PT. Semen Baturaja & 228.570 & 0,3 \\
& (Persero), Tbk & 2.477 .194 & 3,6 \\
7 & PT. Semen Kupanh & 2.135 .203 & 3,1 \\
8 & PT. Semen Bosowa Maros & 1.337 .224 & 1,9 \\
9 & PT. Cemindo Gemilang & 719.186 & 1,0 \\
10 & PT. Jui Shin Indonesia & 1.310 .596 & 1,9 \\
11 & PT. Sinar Tambang & 3.343 .052 & 4,8 \\
& Arthalestari & & \\
12 & PT. Semen Jawa & $\mathbf{6 9 . 5 4 1 . 0 5 3}$ & $\mathbf{1 0 0 , 0}$ \\
13 & PT. Conch Cement & Indonesia & \multicolumn{1}{c}{ Total }
\end{tabular}

Source: Indonesian Cement Association (ASI).

Published By:
Blue Eyes Intelligence Engineering $\&$ Sciences Publication

(C) Copyright: All rights reserved.

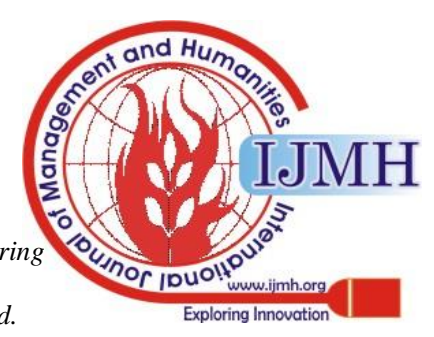


Table 3. Market Share of Semen Baturaja against Semen Indonesia Production

\begin{tabular}{|c|c|c|c|c|c|c|}
\hline Province & $\begin{array}{l}2013 \\
(\%)\end{array}$ & $\begin{array}{l}2014 \\
(\%)\end{array}$ & $\begin{array}{l}2015 \\
(\%)\end{array}$ & $\begin{array}{l}2016 \\
(\%)\end{array}$ & $\begin{array}{l}2017 \\
(\%)\end{array}$ & $\begin{array}{l}2018 \\
(\%)\end{array}$ \\
\hline Riau & 0,00 & 0,00 & 0,00 & 0,00 & 0,00 & 0,00 \\
\hline $\begin{array}{l}\text { Kepulauan } \\
\text { Riau }\end{array}$ & 0,00 & 0,00 & 0,00 & 0,00 & 0,00 & 0,00 \\
\hline Jambi & 2,91 & 1,01 & 2,07 & 7,18 & 6,87 & 6 \\
\hline $\begin{array}{l}\text { Sumatera } \\
\text { Selatan }\end{array}$ & 47,12 & 47,24 & 56,02 & 54,59 & 48,95 & 58 \\
\hline $\begin{array}{l}\text { Bangka } \\
\text { Belitung }\end{array}$ & 0,00 & 0,00 & 0,00 & 0,00 & 0,00 & 1 \\
\hline Bengkulu & 8,87 & 2,02 & 2,06 & 3,81 & 4,50 & 2 \\
\hline Lampung & 26,99 & 21,70 & 22,34 & 24,08 & 21,21 & 32 \\
\hline Banten & 0,00 & 0,00 & 0,00 & 0,00 & 0,00 & 0,00 \\
\hline
\end{tabular}

Source: Indonesian Cement Association (ASI), PT Semen

Baturaja (Persero) Tbk., processed results.

Refer to Table 3, it can be described about the role of PT. Semen Baturaja (Persero) Tbk. in the market area in 8 (eight) provinces compared to national production is still relatively limited. The low market share of PT. Semen Baturaja (Persero) Tbk. compared to National Cement production indicates that there is an increase in National Production which can be caused by an increase in the number of Cement Companies. In 2017 the market share of $48.95 \%$, where prices and promotions play a role to enlarge the market share in accordance with production capacity. In 2018 there was an increase compared to 2017 at 58\% which showed that prices and promotions were influential to increase market share in accordance with production capacity.

Table 4. Market Share of Semen Baturaja against the Cement Market in the Region 8 Provinces

\begin{tabular}{|c|c|c|c|c|c|c|}
\hline Province & $\begin{array}{l}2013 \\
(\%)\end{array}$ & $\begin{array}{c}2014 \\
(\%)\end{array}$ & $\begin{array}{c}2015 \\
(\%)\end{array}$ & $\begin{array}{l}2016 \\
(\%)\end{array}$ & $\begin{array}{c}2017 \\
(\%)\end{array}$ & $\begin{array}{c}2018 \\
(\%)\end{array}$ \\
\hline Riau & 0,00 & 0,00 & 0,00 & 0,00 & 0,00 & 0,00 \\
\hline $\begin{array}{l}\text { Kepulauan } \\
\text { Riau }\end{array}$ & 0,00 & 0,00 & 0,00 & 0,00 & 0,00 & 0,00 \\
\hline Jambi & 1,39 & 0,58 & 0,92 & 3,08 & 3,32 & 14,00 \\
\hline $\begin{array}{l}\text { Sumatera } \\
\text { Selatan }\end{array}$ & 61,54 & 69,67 & 74,28 & 69,23 & 66,16 & 54,00 \\
\hline $\begin{array}{l}\text { Bangka } \\
\text { Belitung }\end{array}$ & 0,00 & 0,00 & 0,00 & 0,00 & 0,00 & 5,00 \\
\hline Bengkulu & 3,76 & 0,84 & 0,77 & 1,65 & 2,52 & 8,00 \\
\hline
\end{tabular}

Source: Indonesian Cement Association (ASI), PT Semen Baturaja (Persero) Tbk., processed results.

Table 4 illustrates the position of the Baturaja cement in the 8 (eight) market regions that have been determined. This condition indicates that competition in the cement market is getting tougher and PT. Semen Baturaja (Persero) Tbk needs to determine strategic steps in order to survive and increase its market share in 8 (eight) market areas that already exist but focus on sales in only 4 (four) Provinces. PT. Semen Baturaja (Persero), Tbk needs to determine the right marketing strategy that can increase sales and maximize profits. To determine the right and efficient marketing strategy, it is very important to research the Prices and Promotions that influence Consumer Decisions on the purchase of cement of PT. Semen Baturaja (Persero) Tbk.

Refer to such description before, the authors have interest in conducting research on "The Effect of Prices and Promotions on Purchase Decisions on Cement at PT. Semen Baturaja (Persero), Tbk".

\section{A. Problem Formulation}

Refer to the background of such problems, problem formulation can be identified in this research, into several important questions, explained as bellows:

1) How does the price influence the cement purchase decision at PT. Semen Baturaja (Persero), Tbk?

2) What is the effect of promotion on cement purchase decisions at PT. Semen Baturaja (Persero), Tbk?

\section{B. Research Objectives}

1) Finding empirical evidence by analyzing the influence of prices on cement purchase decisions at PT. Semen Baturaja (Persero), Tbk.

2) Finding empirical evidence by analyzing the influence of promotions on cement purchase decisions at PT. Semen Baturaja (Persero), Tbk.

\section{Benefits}

1) Practical Benefits

For The Company, as source of information and also reference for the company regarding to marketing management as a valuable material for evaluation and the future consideration for decision making.

2) Theoretical Benefits

For Further Researchers, the results of this research are useful for adding information and research contributions as well as being a reference for other Parties who want to conduct research on purchase decisions.

\section{LITERATURE REVIEW}

\section{A. Purchase Decision}

Purchase decisions are a stage where consumers have a choice and are ready to make purchases or exchanges between money and promises to pay with ownership rights or use of an item or service (Kotler, 2012) [16]. Purchase decisions define as one stage for consumers to choose what products / services they want to buy. Purchase decisions will arise if consumers feel interested and need a product or service.

\section{B. Price}

Price is a sum of money that is billed for a product or service or the amount of value that is exchanged by customers to benefit from owning or using a product or service (Kotler and Armstrong, 2012: 345) [16]. Price is also the nominal amount given to the product or service to notify consumers about what needs to be paid about the product or service.

\section{Promotion}

Promotion is a form of marketing communication in the form of marketing activities that tries to disseminate information, influence or persuade and remind the market of the company or product to be willing to accept, buy and be loyal to the products offered by the company concerned (Tjiptono, 2012: 219) [36].

Published By:

Blue Eyes Intelligence Engineering

\& Sciences Publication

(C) Copyright: All rights reserved. 
Promotion is also an activity made by a company to carry out marketing activities with the purpose of notifying information and persuading potential customers to purchase goods or services.

\section{Variables and Hypotheses Development Relationship}

\section{1) Price Influence (X1) against Purchase Decisions (Y)}

Price is a nominal amount of money given to an item or service that is meaningful to provide a nominal value of money that will be paid by consumers to an item or service. Price is the main factor of consumers to decide on purchases, because consumers will buy the product or service if the price given or offered by the producer is in accordance with the quality of the product or service provided. The consumer will decide to make a purchase if the price given by the producer is in accordance with the quality of the product.

H1: Prices have a positive value and significant influence on Purchase Decisions

\section{2) Promotion Influence (X2) against Purchase Decisions (Y)}

Promotion is one of the company's activities to interact with consumers and carry out activities that have purpose to inform about the products or services sold. Consumers will be interested if the promotional strategies created by the company attract and benefit consumers. Consumers will make purchases of a product or service if consumers can carry out promotional strategies that make consumers want to decide to buy a product or service. If promotions are carried out by producers by attracting consumers, consumers will also decide to purchase a product.

H2: Promotion has a positive value and significant influence on Purchase Decisions.

\section{E. Conceptual Thinking Framework}

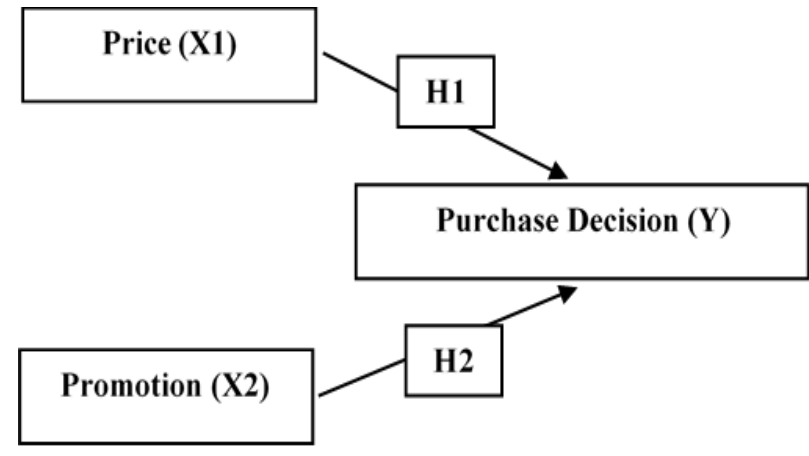

Figure 1. Research Conceptual Framework

\section{RESEARCH METHODS}

This research has objective to measure the interconnections between research variables or causality. Causal research is useful to measure the interconnections between research variables and also to analyze and see the influence of the independent variable $(\mathrm{X})$ against the dependent variable $(\mathrm{Y})$.

The grand planning of this research can be explain further, as follows:

1. Variable X (independence Variables), named by Price and Promotion.
2. Variable Y (dependence Variable), named by the Purchase Decision.

The type of sample used is purposive sampling. The sample used in the implementation of this research amounted to 150 respondents.

The research location is in the city of Palembang and the time of the study was carried out since February 2019 until July 2019.

The analysis technique, using multiple linear regression analysis, the equation as follows:

$$
\mathbf{Y}=\mathbf{a}+\mathbf{b} \_1 \text { X_1+b_2 X_2+e }
$$

Where:

$$
\begin{array}{ll}
\mathrm{Y} & =\text { Purchase decision variable } \\
\mathrm{X} 1 & =\text { Price variable } \\
\mathrm{X} 2 & =\text { Promotion variable } \\
\mathrm{a} & =\text { Constants } \\
\mathrm{b} 1 & =\text { Regression coefficient } \\
\mathrm{e} & =\text { Error }
\end{array}
$$

\begin{tabular}{|c|c|c|c|c|c|}
\hline Indicator & $\begin{array}{c}\text { Product } \\
\text { Moment } \\
\text { Pearson's }\end{array}$ & Sig. & & $\alpha$ & Remarks \\
\hline $\mathrm{X} 1.1$ & 0,492 & 0,006 & $<$ & 0,05 & Valid \\
\hline X1.2 & 0,389 & 0,000 & $<$ & 0,05 & Valid \\
\hline X1.3 & 0,651 & 0,000 & $<$ & 0,05 & Valid \\
\hline X1.4 & 0,445 & 0,000 & $<$ & 0,05 & Valid \\
\hline X1.5 & 0,642 & 0,000 & $<$ & 0,05 & Valid \\
\hline X1.6 & 0,663 & 0,000 & $<$ & 0,05 & Valid \\
\hline $\mathrm{X} 1.7$ & 0,712 & 0,000 & $<$ & 0,05 & Valid \\
\hline X1.8 & 0,682 & 0,003 & $<$ & 0,05 & Valid \\
\hline X1.9 & 0,466 & 0,010 & $<$ & 0,05 & Valid \\
\hline X1.10 & 0,799 & 0,000 & $<$ & 0,05 & Valid \\
\hline X2.1 & 0,579 & 0,001 & $<$ & 0,05 & Valid \\
\hline $\mathrm{X} 2.2$ & 0,671 & 0,000 & $<$ & 0,05 & Valid \\
\hline X2.3 & 0,760 & 0,000 & $<$ & 0,05 & Valid \\
\hline $\mathrm{X} 2.4$ & 0,545 & 0,002 & $<$ & 0,05 & Valid \\
\hline X2.5 & 0,719 & 0,000 & $<$ & 0,05 & Valid \\
\hline X2.6 & 0,590 & 0,001 & $<$ & 0,05 & Valid \\
\hline $\mathrm{X} 2.7$ & 0,291 & 0,119 & $<$ & 0,05 & Not Valid \\
\hline $\mathrm{X} 2.8$ & 0,488 & 0,006 & $<$ & 0,05 & Valid \\
\hline X2.9 & 0,741 & 0,000 & $<$ & 0,05 & Valid \\
\hline $\mathrm{X} 2.10$ & 0,770 & 0,000 & $<$ & 0,05 & Valid \\
\hline Y.1 & 0,103 & 0,589 & $<$ & 0,05 & Not Valid \\
\hline Y.2 & 0,329 & 0,076 & $<$ & 0,05 & Not Valid \\
\hline Y.3 & 0,459 & 0,011 & $<$ & 0,05 & Valid \\
\hline Y.4 & 0,619 & 0,000 & $<$ & 0,05 & Valid \\
\hline Y.5 & 0,479 & 0,007 & $<$ & 0,05 & Valid \\
\hline Y.6 & 0,435 & 0,016 & $<$ & 0,05 & Valid \\
\hline Y.7 & 0,513 & 0,004 & $<$ & 0,05 & Valid \\
\hline Y.8 & 0,631 & 0,000 & $<$ & 0,05 & Valid \\
\hline Y.9 & 0,728 & 0,000 & $<$ & 0,05 & Valid \\
\hline Y.10 & 0,578 & 0,001 & $<$ & 0,05 & Valid \\
\hline
\end{tabular}

\section{RESULTS AND DISCUSSION}

\section{A. Research Results}

\section{1) Validity Test}

Table 5. Validity Test Results

Source: Questionnaire 2019, processed results. 
The value of Product Moment Pearson's have significance figure $<0.05$, and then the indicators (items) in this research variable are suitable and relevant, the items will be proper to be used for data collection.

A few indicators that are still invalid on indicators X2.7, Y.1 and Y.2 which have a significance value> 0.50 .

\section{2) Reliability Test}

Table 6. Reliability Test Results

\begin{tabular}{lcccc}
\hline \multicolumn{1}{c}{ Variable } & $\begin{array}{c}\text { Cronbach's } \\
\text { Alpha }\end{array}$ & $\begin{array}{c}\text { Cut } \\
\text { Off }\end{array}$ & $\begin{array}{c}\text { N of } \\
\text { Item }\end{array}$ & Remarks \\
\hline Price (X1) & 0,799 & $>0,60$ & 10 & Reliable \\
Promotion & 0,816 & $>0,60$ & 10 & Reliable \\
(X2) & & & & \\
Purchase & 0,658 & $>0,60$ & 10 & Reliable
\end{tabular}

Decision (Y)

Source: Questionnaire 2019, processed results.

Reliability Coefficient (Cronbach's Alpha) > 0,60, then measured variables (X1, X2 and Y) are reliable.

3) Normality Test

Table 7. Normality Test Results

\begin{tabular}{lllll}
\hline \multirow{2}{*}{ Test of Normality } & \multicolumn{3}{l}{ Kolmogrov-Smirnov } & \\
& Sig. & & Cut & Remarks \\
\hline Price & 0,152 & $>$ & 0,05 & Normal \\
Promotion & 0,123 & $>$ & 0,05 & Normal \\
Purchase Decision & 0,145 & $>$ & 0,05 & Normal \\
\hline
\end{tabular}

Source: Questionnaire 2019, processed results.

Significance for each variable has bigger figure than 0.05 , it can be concluded the data distribution is normal.

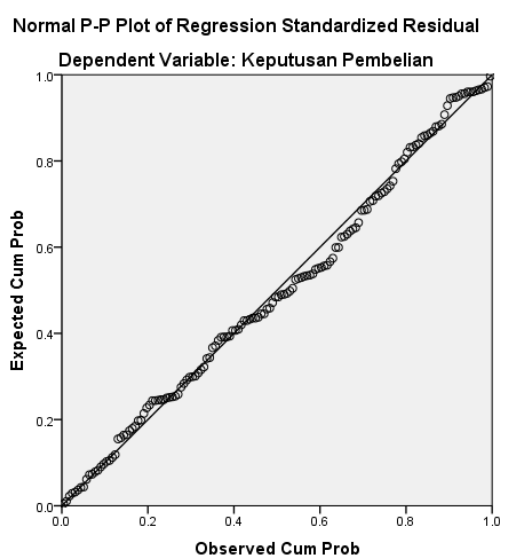

Figure 2. Normality Test Results

Data spreads near and in follow the diagonal line, it can be concluded the regression model suit with normality assumptions.

\section{4) Multicollinearity Test}

Table 8. Multicollinearity Test Results

\begin{tabular}{lcccc}
\hline $\begin{array}{c}\text { Test of } \\
\text { Multicollinearity }\end{array}$ & VIF & & Cut Off & Remarks \\
\hline Price & 1.267 & $<$ & 10 & not occur \\
Promotion & 1.267 & $<$ & 10 & not occur \\
\hline
\end{tabular}

Source: Questionnaire 2019, processed results.

It describes, it does not happen for multicollinearity in the test.

\section{5) Heteroscedasticity Test}

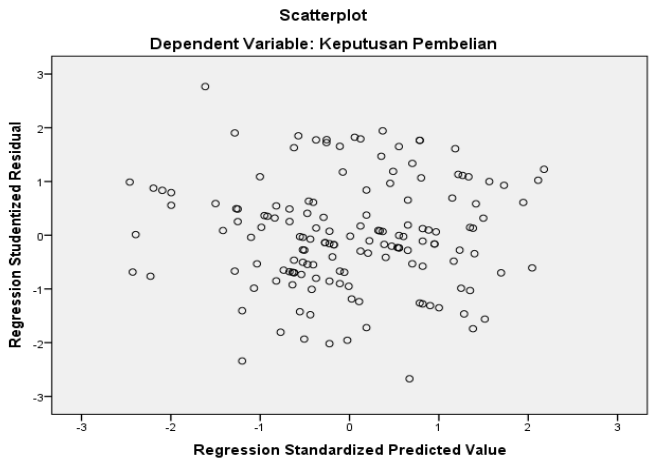

Figure 3. Heteroscedasticity Test Results

Heteroscedasticities do not happen, the spread of points don not form line or pattern, and the point spread above and below zero on $\mathrm{Y}$ axis.

6) Analysis of Multiple Linear Regression Table 9. Results of the Regression Coefficient

\begin{tabular}{|c|c|c|c|c|c|c|}
\hline \multirow{3}{*}{$\begin{array}{c}\text { Model } \\
1\end{array}$} & \multicolumn{4}{|c|}{ Coefficients } & \multirow{3}{*}{ t } & \multirow{3}{*}{ Sig. } \\
\hline & & \multicolumn{2}{|c|}{$\begin{array}{l}\text { Unstandardized } \\
\text { Coefficients }\end{array}$} & \multirow{2}{*}{$\begin{array}{c}\begin{array}{c}\text { Standardized } \\
\text { Coefficients }\end{array} \\
\text { Beta }\end{array}$} & & \\
\hline & & B & $\begin{array}{l}\text { Std. } \\
\text { Error }\end{array}$ & & & \\
\hline & (Constant) & 25.208 & 2.958 & & 8.523 & 0,000 \\
\hline & Price & 0,171 & 0,064 & 0,229 & 2.652 & 0,009 \\
\hline & Promotion & 0,199 & 0,083 & 0,207 & 2.397 & 0,018 \\
\hline
\end{tabular}

Dependence Variables: Purchase Decisions

Source: Questionnaire 2019, processed results.

Data processed by the SPSS 22 program, a regression equation can be formed which explains the influence between the research variables as follows:

$$
\begin{aligned}
& \mathbf{Y}=\mathbf{a}+\mathbf{b}_{1} \mathbf{X}_{1}+\mathbf{b}_{2} \mathbf{X}_{2}+\varepsilon \\
& Y=25.208+0,171 X_{1}+0,199 X_{2}+2.958 \varepsilon
\end{aligned}
$$

The regression model can be explained that a positive constant value of 25,208 shows a positive influence between the price independent variable (X1) by value 0.171 , and also a positive influence between the independent variables of promotion (X2) by value 0.199 on the dependent variable of purchase decisions (Y), it is concluded that the customer is influenced by the independent variables of price and promotion (X).

\section{7) Correlation Coefficient (R) and Determination Coefficient $\left(\mathbf{R}^{2}\right)$}


Table 10. Correlation (R) and Coefficient of Determination Test Results $\left(\mathbf{R}^{2}\right)$ ANNOVA $^{\mathrm{b}}$

\begin{tabular}{ccccc}
\hline Model & $\mathbf{R}$ & $\begin{array}{c}\text { R } \\
\text { Square }\end{array}$ & $\begin{array}{c}\text { Adjusted } \\
\text { R Square }\end{array}$ & $\begin{array}{c}\text { Std. Error } \\
\text { of the } \\
\text { Estimate }\end{array}$ \\
\hline 1 & 0,372 & 0,138 & 0,127 & 4.321 \\
\hline
\end{tabular}

Source: Questionnaire 2019, processed results.

The test results of the coefficient of determination $\left(\mathrm{R}^{2}\right)$ show that the magnitude of the influence of the independent variables on the dependent variable is equal to 0.372 or $37.2 \%$. While the amount of the $\mathrm{R}$ square $\left(\mathrm{r}^{2}\right)$ is 0.138 or equal to $13.8 \%$, the figure is used to see how the prices owned by the PT. Semen Baturaja (Persero), Tbk and how promotions explain purchase decisions.

This number has the intention that how the price and promotion variables provide the information needed to explain the purchase decisions together by $13.8 \%$ while the remaining $86.2 \%(100 \%-13.8 \%)$ are influenced by other factors.

\section{8) Feasibility Test Model (Test F)}

Table 11. Model Feasibility Test

\begin{tabular}{|c|c|c|c|c|c|c|}
\hline \multicolumn{7}{|c|}{ ANNOVA $^{\mathrm{b}}$} \\
\hline Model & & $\begin{array}{c}\text { Sum of } \\
\text { Squares }\end{array}$ & Df & $\begin{array}{c}\text { Mean } \\
\text { Square }\end{array}$ & $\mathbf{F}$ & Sig. \\
\hline \multirow[t]{3}{*}{1} & Regression & 440.685 & 2 & 220.343 & 11.801 & $.000^{a}$ \\
\hline & Residual & 2744.647 & 147 & 18.671 & & \\
\hline & Total & 3185.333 & 149 & & & \\
\hline
\end{tabular}

Dependence Variable : Purchase Decision

Source: Questionnaire 2019, processed results.

Results of value $\mathrm{F}_{\text {count }}$ is 11.801 , bigger than the value of $F_{\text {table }}$ by confidence of $94 \%$, both of price (X1) and promotion (X2) influence significantly on purchase decisions (Y).

\section{9) Individual Parameter Significance Test (t Test)}

Table 12. Results of the Regression Coefficient

\begin{tabular}{|c|c|c|c|c|c|c|}
\hline & & & fficient & & & \\
\hline Model & & $\begin{array}{r}\text { Unstanc } \\
\text { Coeff }\end{array}$ & $\begin{array}{l}\text { rdized } \\
\text { ents }\end{array}$ & $\begin{array}{c}\text { Standardized } \\
\text { Coefficients }\end{array}$ & $\mathbf{t}$ & Sig. \\
\hline 1 & & B & $\begin{array}{l}\text { Std. } \\
\text { Error }\end{array}$ & Beta & & \\
\hline & (Constant) & 25.208 & 2.958 & & 8.523 & 0,000 \\
\hline & Price & 0,171 & 0,064 & 0,229 & 2.652 & 0,009 \\
\hline & Promotion & 0,199 & 0,083 & 0,207 & 2.397 & 0,018 \\
\hline
\end{tabular}

Dependence Variable : Purchase Decision

Source: Questionnaire 2019, processed results.

Price (X1), beta is 0.229 with a significant 0.009 , smaller than 0.05 , Promotion (X2), beta is 0.207 with a significance 0.018 , smaller than 0.05 , both of them influence positively on purchase decisions.

\section{DISCUSSION}

\section{A. Influence of Price (X1) on Purchase Decisions (Y)}

The results of the research found that the consumer's decision to make a purchase was to see the price of the product to be purchased. If the price of the product offered meet requirement with the quality of the product, the consumer will decide to purchase a product. At the company
PT. Semen Baturaja (Persero), Tbk needs to pay attention to the cement prices they offer to consumers. The price of cement set needs to be considered for product quality and price for competing products. The company needs to conduct research before determining the price and target of purchase so that the price of cement is set according to the quality and target that consumer will purchase cement.

The results of this research are suitable with the results of research from Vania (2019); Ahmad (2017); Arif (2017); Christy (2017); Arifin (2017); Herlina (2017); Selvie (2017); Wanda (2017); Arianto (2016); Arum (2016); Melita (2016); Milly (2016); Mardianam (2013); Novi (2016); Rizki (2016); Daniel (2015); Grace (2015); Sandy (2015); Tanihattu (2013) supports that Price has a positive value and significant influence on Purchase Decisions.

\section{B. Influence of Promotion (X2) on Purchase Decisions (Y)}

The Company promote their products to get the attention of consumers who then make purchases. PT. Semen Baturaja (Persero), Tbk needs to improve quality in delivering cement product information to consumers. Officers in conveying information use sentences, vocabulary and language that can be understood and understood by all consumers, besides that officers also need to increase interaction and socialization to consumers to introduce any cement products produced and produced by PT. Semen Baturaja (Persero), Tbk so that consumers better understand and recognize the various types of products produced.

The results of the research are suitable with the results of research from Vania (2019); Putri (2018); Arif (2017); Selvie (2017); Andrew (2016); Arianto (2016); Arum (2016); Melita (2016); Novi (2016); Marnisah (2016); Rizki (2016); Achmad (2015); Daniel (2015); Grace (2015); Sandy (2015); Rindang (2014); Jilly (2013); Kretiawan (2013); Lidya (2013); Tanihattu (2013) supports that Promotion has a positive value and significant influence on Purchase Decisions.

\section{Research Implications}

Theoretical implications, the results of this research indicate that the price variable significantly influences the purchase decision, as well as the promotion variable significantly influences the purchase decision. Thus, these findings can provide benefits to enrich the concept or theory to support the development of marketing management science, especially those related to Price, Promotion and Purchase Decisions.

Practical implications, this research shows the results where the price variable influences the purchase decision, as well as the promotion variable influences the purchase decision which means that the price and promotion can influence the purchase decision. This research can also be used as input in formulating marketing strategies and decision making related to product quality and promotion and can provide a view for marketing managers in developing strategies to market their products effectively and efficiently.

Published By:

Blue Eyes Intelligence Engineering \& Sciences Publication

(C) Copyright: All rights reserved. and $\mathrm{Hu}$ 
Table 13. Summary of Research Results

\begin{tabular}{|c|c|c|}
\hline No. & Hypothesis & Research Results \\
\hline 1 & $\begin{aligned} \text { Ha : } & \text { Price influences on } \\
& \text { purchase decision } \\
\text { Ho : } & \text { Price influences on } \\
& \text { purchase decision }\end{aligned}$ & $\begin{array}{l}\text { H1: Price influences on } \\
\text { purchase decision }\end{array}$ \\
\hline 2 & $\begin{aligned} \text { Ha : Promotion influences } & \\
& \text { on purchase decision } \\
\text { Ho : Promotion influences } & \\
& \text { on purchase decision }\end{aligned}$ & $\begin{aligned} \text { H2: Promotion influences } \\
\text { on purchase decision }\end{aligned}$ \\
\hline
\end{tabular}

Source: Questionnaire 2019, processed results.

\section{CONCLUSION AND RECOMMENDATIONS}

\section{A. Conclusions}

In this research, the test results use method by multiple linear regression analysis by using 2 (two) independent variables, they are Price and Promotion and dependent variable Purchase Decision, having explanation as follows:

1) Prices variable influence positively and significant on purchase decisions.

2) Promotions variable influence positively and significant on purchase decisions.

\section{B. Recommendations}

According to the research results, discussion, conclusions above, the recommendations are proposed, the explanation as follows:

1) The cement price offered by PT. Semen Baturaja (Persero), Tbk is already good, the cement price needs to provide competitive prices in order cement products can be purchased by all consumers.

2) The Promotions have been done well, it needs to be improved in the delivery of information to consumers, in order the consumers can easily recognize and comprehend the information provided

\section{REFERENCES}

1. Achmad J., Zainul A., \& Kadarismasn. 2015. Pengaruh Promosi Online dan Persepsi Harga Terhadap Keputusan Pembelian (Survei Pada Pelanggan Aryka Shop di Kota Malang). Jurnal Administrasi Bisnis (JAB). Vol. 21 No. 1 April 201. Universitas Brawijaya.

2. Ahmad B., \& Edy. 2017. Pengaruh Brand Equity, Harga dan Distribusi Terhadap Keputusan Pembelian Vape (Studi PadaVape Store 5Time). Diponegoro Journal of Management. Volume 6, Nomor 4, Tahun 2017, Halaman 1-10. ISSN (Online): 2337-3792.

3. Andrew F., Manampiring., \& Irvan. 2016. Pengaruh Produk, Harga, Promosi dan Tempat Terhadap Keputusan Pembelian Mobil di PT. Astra International, Tbk Malalayang. Jurnal EMBA. Vol.4 No.1 Maret 2016, Hal. 472-483. ISSN 2303-1174.

4. Arianto S., \& Imroatul. 2016. Analisis Pengaruh Persepsi Harga, Kualitas Pelayanan, Promosi dan Lokasi Terhadap Keputusan Pembelian (Studi pada Floo Cafe Ungaran). Diponegoro Journal of Management. Volume 5, Nomor 4, Tahun 2016, Halaman 1-14. ISSN (Online): 2337-3792.

5. Arif R. N., \& Rizal. 2017. Pengaruh Promosi, Harga, dan Kualitas Pelayanan Terhadap Keputusan Pembelian (Studi Pada Rahma Rahmi Collection). Diponegoro Journal of Management. Volume 6, Nomor 4, Tahun 2017, Halaman 1 - 9. ISSN (Online): 2337-3792.

6. Arum Y., \& Susilo. 2016. Analisis Pengaruh Citra Merek, Produk, Harga dan Promosi Terhadap Keputusan Pembelian (Studi pada Konsumen Bandeng Juwana Elrina). Diponegoro Journal of Management. Volume 5, Nomor 3, Tahun 2016, Halaman 1-11. ISSN (Online): 2337-3792.

7. Christy J. G., Jantje S., \& Sjendry. 2017. Pengaruh Kualitas Produk, Harga dan Promosi Terhadap Keputusan Pembelian Mobil Nissan X-Trail pada PT. Wahana Wirawan Manado. Jurnal EMBA. Vol.5 No.2 Juni 2017, Hal. 2221 - 2229. ISSN 2303-1174.

8. Danang, Sunyoto. 2013. Metodologi Penelitian Akuntansi. Bandung: PT Refika Aditama Anggota Ikapi.

9. Daniel O. R., Azis F., \& Leonardo. 2015. Pengaruh Kualitas Pelayanan, Harga dan Promosi Terhadap Keputusan Pembelian Produk CKE Teknik
Semarang. Jurnal Universitas Diponegoro.

10. Ghozali, Imam. 2013. Aplikasi Multivariate dengan Program SPSS. Edisi Ketujuh. Semarang: Badan Penerbit Universitas Diponegoro.

11. Grace M. W., Lisbeth M., \& Hendra. 2015. Pengaruh Bauran Promosi, Persepsi Harga dan Lokasi Terhadap Keputusan Pembelian dan Kepuasan Konsumen Pada Perumahan Tamansari Metropolitan Manado. Jurnal EMBA. Vol.3 No.2 Juni 2015, Hal. 1073-1085. ISSN 2303-1174.

12. Herlina, L., \& Elpanso, E., 2017. Pengaruh Kualitas Produk, Harga Terhadap Keputusan Pembelian Semen Baturaja (Studi Kasus Pada Tiga Toko Bangunan di Kelurahan Kenten Laut). Jurnal Universitas Bina Darma.

13. Indonesia Cement Statistic. 2017. Indonesia Cement Association (ASI), Jakarta.

14. Indonesia Cement Statistic. 2018. Indonesia Cement Association (ASI), Jakarta.

15. Jilly B. 2013. Promosi, Distribusi, Harga Pengaruhnya Terhadap Keputusan Pembelian Rokok Surya Promild. Jurnal EMBA. Vol.1 No.4 Desember 2013, Hal. 95-104. ISSN 2303-1174..

16. Kotler \& Keller. 2012. Manajemen Pemasaran. Edisi 12. Jakarta: Erlangga.

17. Kotler, Philip, \& Armstrong, Gary. 2014. Prinsip-prinsip Manajemen. Edisi 14, Jilid 1. Jakarta: Erlangga.

18. Krestiawan, Handoyo D. W., \& Sari. 2013. Pengaruh Kualitas Produk, Harga, dan Promosi Terhadap Keputusan Pembelian Permen Tolak Angin di Semarang (Studi Kasus pada Pengguna Permen Tolak Angin di Kelurahan Tembalang Semarang). Diponegoro Journal of Social and Politic. Tahun 2013, Hal. 1-10.

19. Lidya M., Lisbeth M., \& Agusta. 2013. Kualitas Produk, Strategi Promosi dan Harga Pengaruhnya Terhadap Keputusan Pembelian Kartu Simpati Telkomsel di Kota Manado. Jurnal EMBA. Vol.1 No.4 Desember 2013, Hal. 2336-2346. ISSN 2303-1174.

20. Mardianam, D.E.P., 2013. Analisa Pengaruh Harga, Citra Merek dan Kualitas Produk Terhadap Keputusan Pembelian Semen Merek Bosowa di Desa Lojejer. Jurnal Universitas Muhammadiyah Jember.

21. Marnisah, L., Saputra, D., \& Rosni, A.K., Analisa Efektivitas Promosi Terhadap Keputusan Konsumen Pada Membeli Semen Baturaja di Kelurahan Sekip Jaya Kecamatan Kemuning Palembang. Jurnal Ilmiah Ekonomi Global Masa Kini. Volume 7 No. 03 Desember 2016.

22. Melita Y., \& Agustin. 2016. Analisis Kualitas Produk, Harga dan Promosi Terhadap Keputusan Pembelian Motor Honda Vario (Studi Kasus Pada Tridjaya Motor Dealer Resmi Motor Honda Cabang Girian-Bitung). Jurnal Berkala Ilmiah Efisiensi. Volume 16 No. 03 Tahun 2016.

23. Milly L., \& Mokoagouw. 2016. Pengaruh Gaya Hidup, Harga, Kualitas Produk Terhadap Keputusan Pembelian Handphone Samsung di Samsung Mobile IT Center Manado. Jurnal Berkala Ilmiah Efisiensi. Volume 16 No. 01 Tahun 2016.

24. Mudrajat, Kuncoro. 2013. Manajemen Riset untuk Bisnis dan Ekonomi. Edisi 4. Jakarta: Erlangga.

25. Muhammad, Imroatul K. 2017. Analisis Pengaruh Kualitas Produk, Persepsi Harga dan Sikap Terhadap Keputusan Pembelian (Studi pada Pos Ketan Legenda 1967 Kota Semarang). Diponegoro Journal of Management. Volume 6, Nomor 4, Tahun 2017, Halaman 1-11. ISSN (Online): 2337-3792.

26. Novi A., \& Purba. 2016. Pengaruh Bauran Pemasaran (Kualitas Produk, Harga, Promosi dan Saluran Distribusi) Terhadap Keputusan Pembelian Yamaha NMAX di Semarang. Jurnal Universitas Diponegoro.

27. Putri R. P., Agus. S. S., \& Ferdy. 2018. Pengaruh Promosi dan Word of Mouth Terhadap Keputusan Pembelian di Oriflame Manado. Jurnal EMBA. Vol.6 No.4 September 2018, Hal. 3703 - 3712. ISSN 2303-1174.

28. Rindang L., Silvya L. M., \& Agus. 2014. Citra Merek, Harga dan Promosi Pengaruhnya Terhadap Keputusan Pembelian Perhiasan Emas Pada PT. Pegadaian (Persero) Cabang Manado Utara. Jurnal EMBA. Vol.2 No.2 Juni 2014, Hal. 1222-1232. ISSN 2303-1174.

29. Rizki S. H., \& Sutopo. 2016. Analisis Pengaruh Persepsi Harga dan Promosi Terhadap Keputusan Pembelian Konsumen (Studi Kasus pada Warung Spesial Bebek Goreng Andalan). Diponegoro Journal of Management. Volume 5, Nomor 3, Tahun 2016, Halaman 1-10. ISSN (Online): 2337-3792.

30. Sandy S., \& Irvan. 2015. Pengaruh Harga, Lokasi, Promosi dan Kualitas Layanan Terhadap Keputusan Pembelian Pada Toko Komputer Game Zone Mega Mall Manado. Jurnal EMBA. Vol.3 No.3 Sept. 2015, Hal.300-311. ISSN 2303-11.

Published By:

Blue Eyes Intelligence Engineering \& Sciences Publication

(C) Copyright: All rights reserved. 
31. Selvie N., Silvya. L. M., \& Lotje. 2017. Pengaruh Promosi, Harga, Dan Distribusi Terhadap Keputusan Pembelian Pakaian Pada Matahari Departemen Store Manado (Studi Kasus Di Matahari Departemen Store Manado Town Square). Jurnal EMBA. Vol.3 No.2 Juni 2017, Hal. 2221 2229. ISSN 2303-1174.

32. Selvany, Joyce L., \& Silcyljeova. 2015. Pengaruh Kualitas Produk, Harga dan WOM (Word of Mouth) Terhadap Keputusan Pembelian Handphone Evercross Pada CV. Tristar Jaya Globalindo Manado. Jurnal EMBA. Vol.3 No.3 Sept. 2015, Hal.817-826. ISSN 2303-11.

33. Sindy, Tawas. 2013. Atribut Produk, Harga dan Strategi Promosi Pengaruhnya Terhadap Keputusan Pembelian Konsumen Pada Mobil Toyota Vios di PT. Hasjrat Abdi Manado. Jurnal EMBA. Vol.1 No.4 Desember 2013, Hal. 1329-1340. ISSN 2303-1174.

34. Sugiyono. 2012. Metode Penelitian Administrasi, Bandung: CV. Alfabeta.

35. Tanihattu. M.M., 2013. Pengaruh Kualitas Produk, Citra Merek, Harga dan Promosi Terhadap Keputusan Pembelian Semen Tonasa di Kota Ambon. Jurnal Cita Ekonomika. Vol. VII No. 1 Mei 2013.

36. Tjiptono, Fandy, \& Gregorius. 2012. Pemasaran Strategik. Yogyakarta: Andi.

37. Vania S., Silvya L. M., \& Silcyljeova. 2019. Pengaruh Lokasi, Promosi dan Persepsi Harga Terhadap Keputusan Pembelian Konsumen Pada Perumahan Kawanua Emerald City Manado. Jurnal EMBA. Vol.7 No.1 Januari 2019, Hal. 881 - 890. ISSN 2303-1174.

38. www.semenbaturaja.co.id

\section{AUTHORS PROFILE}

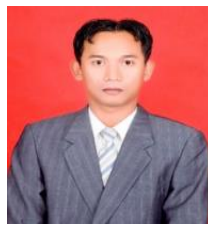

Muhammad Beni, Corresponding Author, Candidate Master of Management in Magister Management University of Sriwijaya, Indonesia.

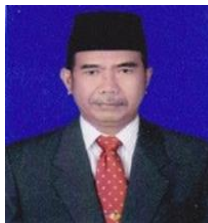

Dr. Zakaria Wahab, M.B.A, Lectures in Faculty Economic University of Sriwijaya, Indonesia.

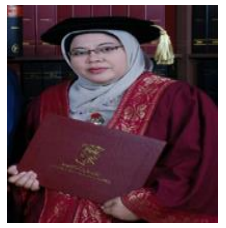

Hj. Marlina Widiyanti, S.E., S.H., M.M., Ph.D., Lectures in Faculty Economic University of Sriwijaya, Indonesia. 